\begin{tabular}{|c|c|c|c|}
\hline & DOI: htt & 021.10 .1 .16 & \multirow{3}{*}{ 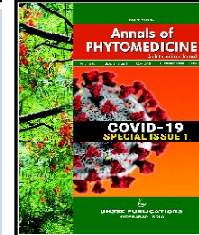 } \\
\hline & $\begin{array}{r}\text { Annal } \\
\text { http://ww }\end{array}$ & $\begin{array}{l}\text { Journal } \\
\text { is/index.php }\end{array}$ & \\
\hline & Print ISSN : 2278-9839 & Online ISSN : 2393-9885 & \\
\hline
\end{tabular}

\title{
Probiotics mediated control and immunomodulation of SARS-CoV-2 associated pathological conditions
}

\author{
P. Saravana Kumari*, V. Viswapriya, M. Lydia Rajakumari* and S. Murugan** \\ Department of Microbiology, Rathnavel Subramaniam College of Arts and Science, Coimbatore-641402, Tamil Nadu, India \\ *Department of Microbiology, Indira Gandhi College of Arts and Science, Kathirkamam, Pondicherry-605009, India \\ **Department of Biotechnology, Karunya Institute of Technology and Sciences, Coimbatore-641114, Tamil Nadu, India
}

\begin{tabular}{|c|c|}
\hline Article Info & Abstract \\
\hline $\begin{array}{l}\text { Article history } \\
\text { Received } 1 \text { May } 2021 \\
\text { Revised } 16 \text { June } 2021 \\
\text { Accepted } 17 \text { June } 2021 \\
\text { Published Online } 30 \text { June } 2021\end{array}$ & $\begin{array}{l}\text { Severe acute respiratory syndrome coronavirus-2 (SARS-CoV-2) is a fast-evolving respiratory infection- } \\
\text { causing virus. The simple structure of the virus enables it to spread through the air and easy lodging into } \\
\text { the respiratory tract of the host. The virus-specific spike protein rendering antigenicity and pathogenicity } \\
\text { in the host. The spike protein is highly evolving as an immunogenic form through mutation. Variants } \\
\text { of the virus are much more pathogenic that induce inflammation during the early stages of infection } \\
\text { and cytokine storm in later stages of infection, which cause cytolysis of own host cells. Drugs used are }\end{array}$ \\
\hline $\begin{array}{l}\text { Keywords } \\
\text { Probiotics } \\
\text { SARS-CoV-2 } \\
\text { Variants of SARS-CoV-2 } \\
\text { Immunomodulation } \\
\text { Treatment of COVID-19 } \\
\text { Mechanism of probiotics }\end{array}$ & $\begin{array}{l}\text { targeted towards spike protein and virus-specific components and several drugs are under trial. A drug } \\
\text { that needs to control the host immune response and maintain homeostasis in the host is required. Anti- } \\
\text { inflammatory drugs and steroids recommended for immunostimulatory and as immunosuppressors } \\
\text { according to the prevailing condition of infection. Several phytomedicines evaluated for their efficiency } \\
\text { to control the pandemic. Another natural system to control viruses is the probiotic organisms, proven } \\
\text { for their ability to competitively inhibit entry and establishment of viral pathogens in the host. } \\
\text { Administration of probiotics during the primary stage of viral infection improves the host immunity } \\
\text { and prevents the increase in viral load and in later stages, regulates the host immunity when host } \\
\text { immunoregulation disrupted by viral antigen. This helps in the immunomodulation of the host immune } \\
\text { system on the whole. The present review evaluates the immunomodulatory effect of probiotics to } \\
\text { control SARS-CoV-2. }\end{array}$ \\
\hline
\end{tabular}

\section{Introduction}

The coronavirus disease 2019 (COVID-19) has imposed major threat to the children, pregnant women, employees, executives, geriatric, patients with chronic complications, researchers and industries. It affected the teaching-learning process, availing necessary healthcare support at times and high risk of getting infection to the mother and infant, regular income, overall productivity and improvisation, psychological effect on safety and well-being, survival of patients with lung problem, hypertension and heart diseases, efficient technology to develop drugs and vaccines (required within short period) and challenged the scientist in mass production of drugs and vaccine to meet huge mass at a short stretch. A mild to moderate respiratory illness caused by severe acute respiratory syndrome coronavirus 2 (SARS-CoV-2) has affected all sectors of human life invariably. Prime mode of transmission is through air, as respiration is indispensable for all life, while respiring aerosols or droplets containing virus lead to the complications associated with COVID19 infection and severe infection in persons with comorbidities. Coronavirus belongs to the family Coronaviridae, subfamily Nidovirales. A comprehensive taxonomic analysis of the viruses in

Corresponding author: Dr. P. Saravana Kumari Associate Professor, Department of Microbiology, Rathnavel Subramaniam College of Arts and Science, Coimbatore-641402, Tamil Nadu, India

E-mail: sarankumaribs@gmail.com

Tel.: +91-9442386269

Copyright (C) 2021 Ukaaz Publications. All rights reserved.

Email: ukaaz@yahoo.com; Website: www.ukaazpublications.com the coronoviridae revealed that humans are the only host for SARSCoV-2 (Evgeny et al., 2020). The first outbreak of COVID-19 and related respiratory sickness was reported in Wuhan, Hubei Province, China during December 2019. The rate of infections is very high and spread across the globe as pandemic. The World Health Organization (WHO) is to keep in track of this pandemic and disseminating relevant updated information continuously. Due to its severity in infection and the high rate of infection, the WHO on January 30, 2020 declared that the SARS-CoV-2 epidemic is a public health emergency of international concern (PHEIC). After that, WHO officially named SARS-CoV-19 infection in human as coronavirus disease-2019 (COVID-19) on February 11, 2020 and the International Committee on Taxonomy of Viruses (ICTV) named the virus as severe acute respiratory syndrome coronavirus 2 (SARSCoV-2). The WHO reported that globally 162.7 million confirmed cases of COVID-19, including 3.3 million deaths on 17 May 2021 and around 1,264,164,553 vaccine doses administered to beneficiaries till 11 May 2021. The average number of transmission of SARS-CoV-2 from one infected person to another ( $\mathrm{R}$ or R0) varied from 1.8 to 3.6 (average of 2.5) across the globe, comparatively higher than the recent pandemics of SARS-CoV (R-value 2.0 to 3.0) and influenza (R-value 1.5) (Petersen et al., 2020). Although, the R number across the UK is now between 0.7 and 0.9, in Scotland's estimated $\mathrm{R}$ number is between 0.8 and 1.0, in Wales the number is between 0.6 and 0.9 , Northern Ireland was 0.75 and 0.95 , England, was between 0.8 and 1.0 and in India it is increased from 1.8 to 2.1 recently. Comparatively, the United States, India, and Brazil are the three countries with the largest cumulative number of confirmed cases in the world. Now, SARS-CoV-2 is recognized as the third 
infection which is zoonotic in origin and transmitted to human of this century and affected a huge mass with $3.4 \%$ of mortality rate (Gralinski and Menachery, 2020).

\section{Structure of SARS-CoV-2}

Coronaviruses belong to the subfamily Coronavirinae in the family of Coronaviridae and belongs to the group beta coronavirus. The genome of SARS-CoV-2 is a single-stranded, linear, positive-sense RNA consists of 29903 nucleotides arranged in 14 open reading frames which is larger than any other RNA viruses (Ankur Das $e t$ al., 2021). Genetic material is coiled with phosphate and capsid protein to form nucleocapsid phosphoprotein $(\mathrm{N})$ covered by an envelope which is associated with four structural proteins: membrane protein (M), spike glycoprotein (S), hemagglutininesterase dimer (HE) and envelope protein (E) coded by Orf 1 (266 to $21,555 \mathrm{nt}$ ), and sixteen non-structural proteins (nsp1"16 coded by Orf 3, 6, 7, 8, 9 and 10) (Tai et al., 2020) (Figure 1). Functions of nsp are nsp1 - inhibition of host mRNA translation and affects signals from IFN, nsp2-survival signaling pathway of host cell, nsp3 - separation of the translated protein, nsp4-transmembrane domain 2 (TM2) and modifies ER membranes, nsp5-processing of polyprotein, nsp6-presumptive transmembrane domain, $\mathrm{nsp} 7$ and nsp8-increase the stable binding of nsp12 and template-primer 7SLRNA, nsp9-single stranded RNA-binding protein, nsp10- cap methylation of viral mRNAs, nsp12-RNA-dependent RNA polymerase (RdRp-for coronavirus replication/transcription), nsp13binds with ATP and the zinc-binding domain to participate in the replication and transcription, and nsp14-proofreading exoribonuclease domain, nsp15-Mn(2+)-dependent endoribonu-clease activity and nsp16 - 2'-O-ribose methyltransferase and host mRNA splicing (Naqvi et al., 2020). NSP1 binds to 18 S ribosomal RNA in the mRNA entry channel of the ribosome to interfere with the translation of mRNA. NSP8 and NSP9 bind to the 7SL RNA which located at the 'signal recognition particle' to disrupt protein trafficking to the cell membrane (Banerjee et al., 2020).

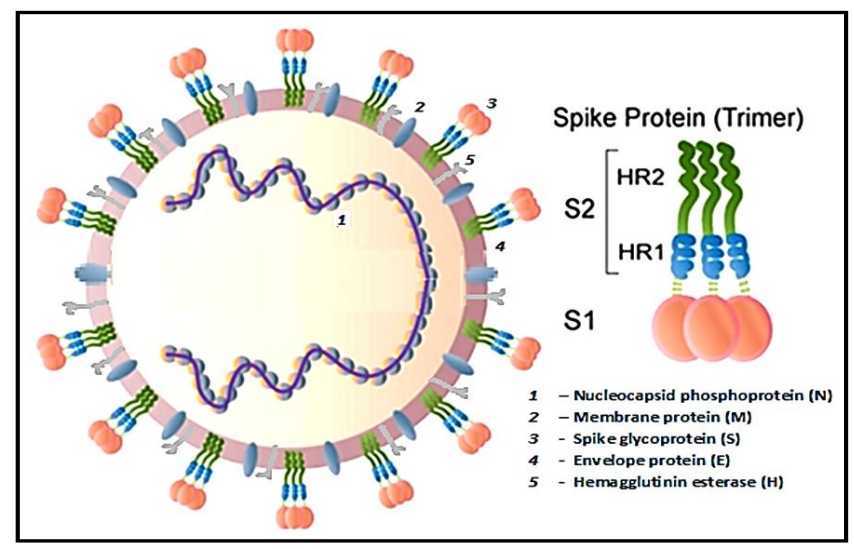

Figure 1: Structure of SARS-CoV-2 proteins.

\subsection{Santigen}

Santigen or spike glycoprotein plays important role in recognition and attachment of virus to the host cells. It is a homotrimer S1, S2 and transmembrane segments. S1 is consists of five antiparallely arranged beta strands linked by disulphide bonds referred as $\mathrm{N}$ terminal domain (NTD) or receptor binding domain (RBD) binds to angiotensin-converting enzyme-02 (ACE-2) receptor present on the lungs, cardiovascular system, gut, kidneys, central nervous system, and adipose tissue of the human.
S2 subunit consists of a fusion peptide (FP), trimmers of heptad repeat 1(HR1), trimeric coiled - heptad repeat 2(HR2), central helix $(\mathrm{CH})$, connector domain (CD), transmembrane domain (TM), and cytoplasmic tail (CT) which connects S1 domain with the virus. Proper folding of s-protein and neutralizing antibodies are associated with the glycans present on the S1 subunit and the whole domain protruded outside the virus during the time of infection (Wrapp et al., 2020). The HR1 and HR2 domains are linked by a hydrogen bond between lysine at 933 position in HR 1 and asparagine at 1,192 position in HR2. Seventeen of the 20 residues of the ACE2 receptor interact with the RBD of SARS-CoV-2 with high affinity and forms a stable interaction the host (Figure 2).

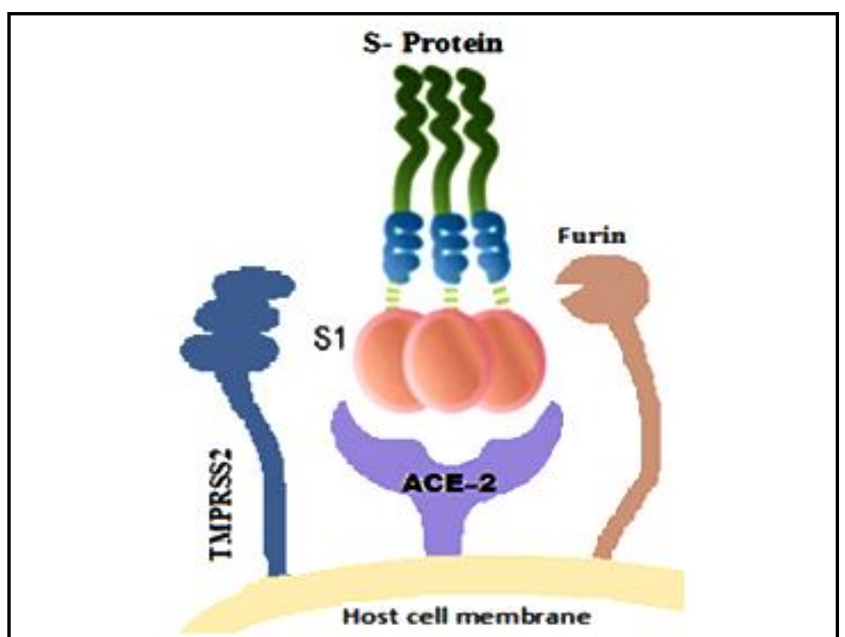

Figure 2: Interaction of S-protein with ACE-2 receptor on cell membrane.

Transmembrane serine protease-2 (TMPRSS2) is a surface protein expressed on endothelial cell that is involved in activation of spike protein in SARS-CoV-2 along with furin. To activate the S1 protein, cleaved by furin protease present near the ACE-2 receptor. It cleave linking region between S1 and S2 subunit on the human cell.The furin cleavage site includes P681, R682, R683, and A684. Loss of these cleavage site completely affects the pathogenesis of the virus by loss of binding function with ACE-2 receptor (Wang et al., 2020). Emma et al. (2020) described a rapid rise of SARS-CoV-2 infections due to the substitution at position S:677 polymorphism of the S gene that lead to 6 distinct variants suggest a selective advantage of the virus to escape from immune system and drugs.

\subsection{The RNA-dependent RNA polymerase (RdRp)}

The replication and transcription of SARS-CoV-2 is mediated through a combination of viral nsp and RNA dependent RNA polymerase in nsp 12, 7 and 8 complex. The nsp 12 has $\mathrm{N}$-terminal end with a unique hairpin loop and C-terminal end which are linked by an interface domain. The RNA-dependent RNA polymerase domain consists of fingers subdomain, a palm subdomain, and a thumb subdomain (Wang et al., 2020) (Figure 3). The subunit nsp12 binds with the first turn of RNA between thumb domains and fingers domains. The active site of palm subdomain contains five nsp12 motifs A-E. The nsp8 extensions use the positively charged residues to interact with the RNA backbones. The nsp8 as the "sliding poles", slide on the protruding RNA to prevent RdRp from dissociating prematurely during replication. The triphosphate-binding site is 
conserved. Residues D623, S682, and N691 are interacts with the 2'-OH group of triphosphate (NTP), making the RdRp special for the synthesis of RNA (Wang et al., 2020).

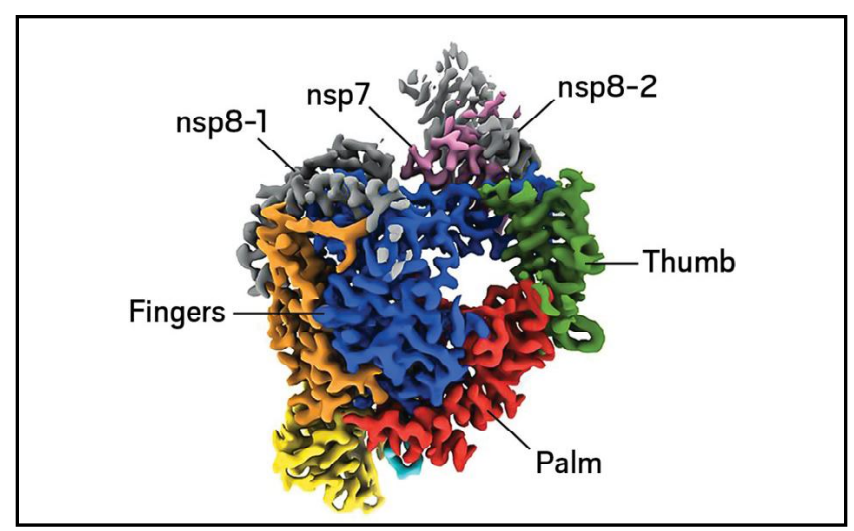

Figure 3: RNA-dependent RNA polymerase of SARS-CoV-2 (American Chemical Society).

\subsection{The main protease}

The main protease $\left(\mathrm{M}^{\mathrm{pro}}\right)$ of SARS-CoV-2 plays a pivotal role in mediating the replication and transcription of viral gene. Inactive form of RdRp, nsp-13 and polyproteins (ppla and pp1ab that is between nsp-4 and nsp-6) required for viral replication are cleaved by $\mathrm{M}^{\text {pro }}$ at eleven conserved sites. It belongs to the group cysteine protease with an active site contains cysteine and serine dyad and a water molecule. This has $99 \%$ of identity with bat coronavirus RaTG13 main protein. It is a homodimer of protomer A and protomer B, and each protomer contains 3 subdomains: domain I, domain II, and domain III. Domain II and domain III are linked by a loop and at the cleft between domain I and domain II lies the substrate-binding pocket (Jin et al., 2020).

Drugs used to control SARS-CoV-2 mainly aims at targets like viral spike protein (S), RNA-dependent RNA-polymerase (RdRp, nsp12), main protease, NTPase/helicase (nsp13) and papain-like protease ( $\mathrm{PL}^{\text {pro }}$, part of $\mathrm{nsp} 3$ ) which are essential for viral replication/ transcription and entirely different from human cellular component.

Table 1: SARS-CoV-2 variants and their adaptive advantages

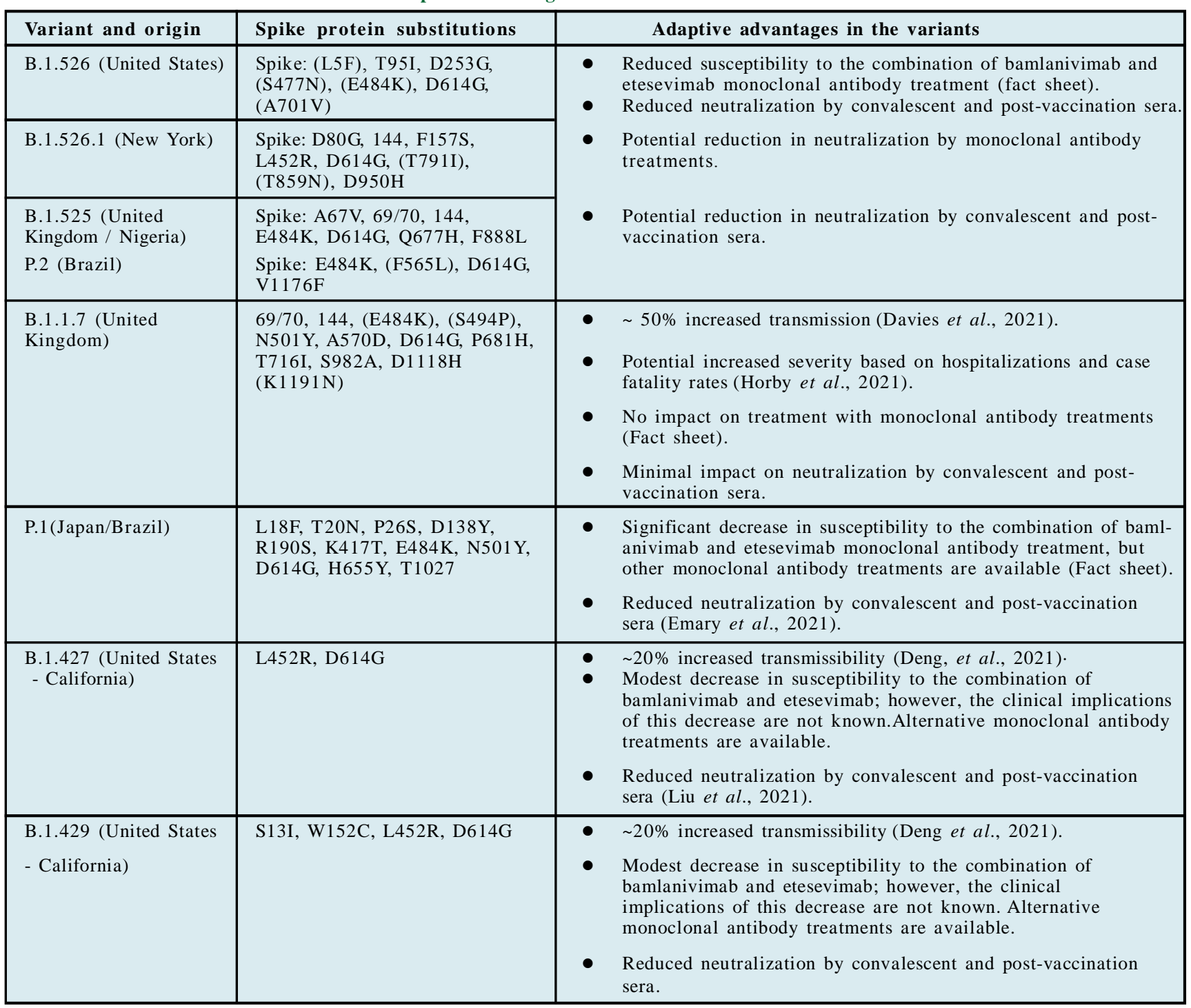




\section{Variants of SARS-CoV-2}

A variant is the organism having one or more mutations that differentiate it from other variants of a species. Globally, the SARSCoV-2 variant having D614G mutation in the spike (S)-protein predominant strain. First recognized variant undergone S-D614 (aspartate) mutated to S-G614 (glutamine). Similar mutants of virus like particles of SARS-CoV-2 produced by mutation in $\mathrm{M}, \mathrm{N}, \mathrm{E}$, and $\mathrm{S}$ proteins. This had increased infection rate of the mutant (Table 1). When mutation frequency of SARS-CoV-2 is calculated, it undergoes mutation at one or two single-nucleotide per genome in a month which is $50 \%$ of rate of mutation of flu virus and $25 \%$ of AIDS virus mutation rateand the overall the mutation rate is slow compared to other RNA viruses. A novel exoribonuclease (ExoN) coded by virus helps in correcting the errors during genome replication. Even though, the major adaptive mechanisms rendered by these mutations are:

- Specific genes to affect transmission, diagnostics, therapeutics, or host immune responses.

- Increased level of outbreak by antigenic variants.

- Significant reduction in vaccine effectiveness or very low vaccine-induced protection.

- Severe pathological condition (hyperoxia) and increased mortality.

3.1 S protein mutations in SARS-CoV-2 variants

Mutations in the $\mathrm{S}$ gene, region responsible for pathogenesis and normal function (such as the receptor binding domain (RBD) or furin cleavage site) or activation of the $\mathrm{S}$ protein, are of the greatest interest. These mutations may provide an avenue for the virus to escape from immunity to the original SARS-CoV-2 strain. First reported mutation in S-protein at site D614G site and the mutant has increased infectivity by assembling more functional $\mathrm{S}$ protein into the virion (Zhang et al., 2020). D614G is a substitutional mutation at 614 position of $S$ protein by replacement of aspartate (D) with glycine $(\mathrm{G})$ that enhanced viral replication in human lung epithelial cells and primary human airway tissues by increasing infectivity and stability of virons (Plante et al., 2021). Novel variant of SARS-CoV-2 is B.1.1.7, commonly referred to the U.K. strain, variant B.1.351 known as 501Y.V2 or the South African variant, P.1., is known as 501Y.V3 or the Brazilian variant; B.1.427 and B.1.429 (Zhang et al., 2021), CAL.20C or the California variant recognized as B.1.526, or the New York variant and multiple lineages of variants that contain mutations at amino acid position 677 (CDC, 2021). SARS-CoV-2 variants have undergone major mutation in cleavage site, in B.1.1.7 substituted from proline $(\mathrm{P})$ to histidine (H) at position 681, B.1.351 and B.1.526 both have undergone an alanine (A) to valine $(\mathrm{V})$ substitution next to the furin cleavage site at 701. A base substitution recorded at the position L452R in B.1.526.1, B.1.427, and B.1.429 also another substitution of at E484K is present in B.1.525, P.2, P.1, and B.1.351, but only some strains of B.1.526 and B.1.1.7. B.1.1.7 variant is associated with increased risk of death compared to other variants (Weisblum et al., 2020) (Figure 4). Similar amino acid changes in the spike protein of B.1.1.7, B.1.351, P.1, B.1.427/B.1.429 and B.1.526 SARS-CoV-2 variants were recorded.

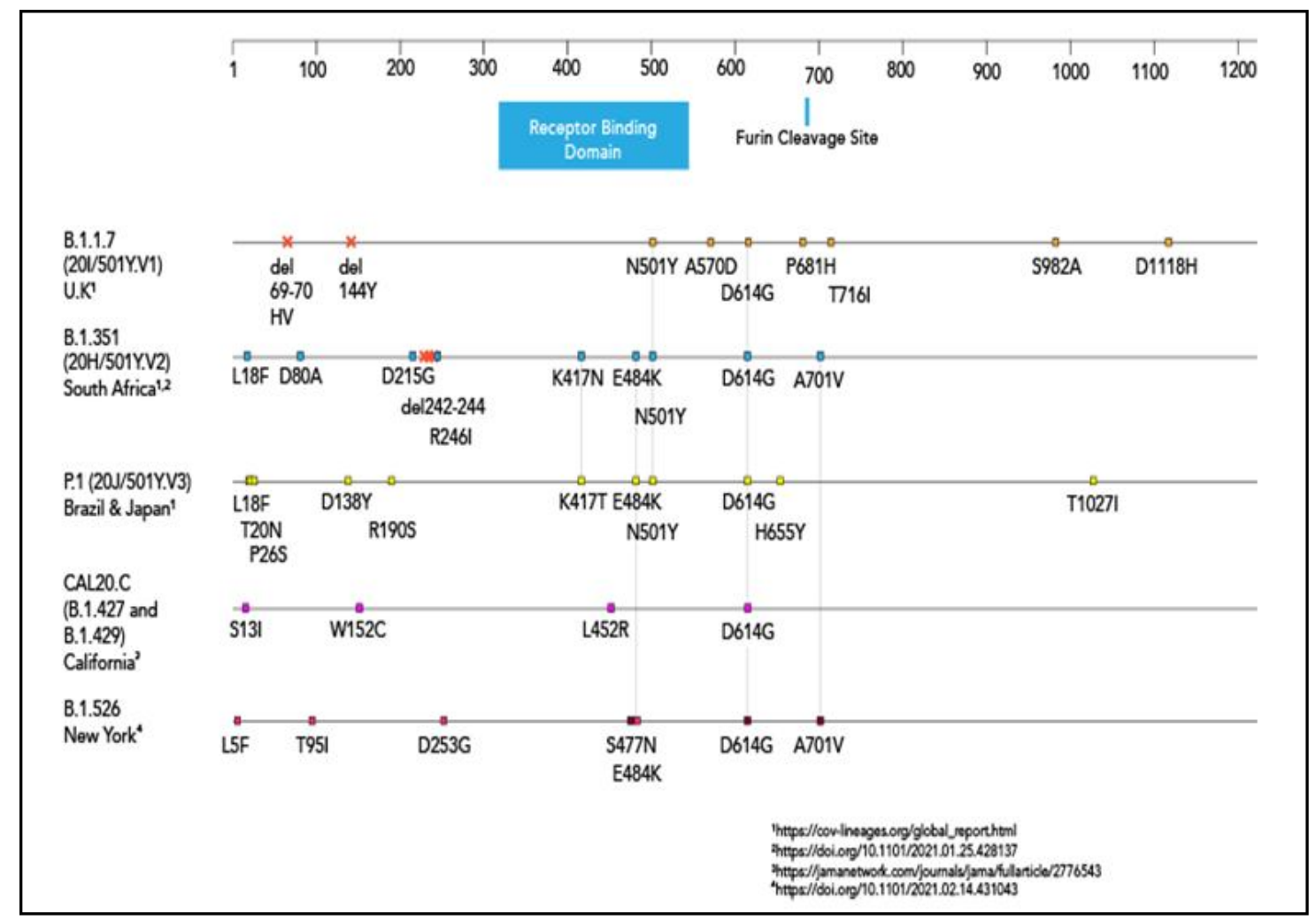

Figure 4: Amino acid changes in the spike (S) protein of SARS-CoV-2 variants.

Source: American Society for Microbiology (Ashley Hagen, 2021). 
Alteration in antigenicity attributed by the deletion of amino acids in the position 69 and 70 mutation in the $\mathrm{N}$-terminal $\mathrm{S}_{1}$ subunit of $\mathrm{S}$ protein cause a conformational change in the spike protein and the emergence of B.1.1.7 variant. Deletion of amino acid 144 in B.1.1.7 and amino acids 242-244 in B.1.351 decreased the binding ability of the virus with neutralizing antibodies (By Kevin et al., 2021).

Substitution of aspartate with glycine at position 253 that appears in B.1.526, helps to escape from monoclonal antibodies against the NTD, and L18F, a leucine (L) to phenylalanine (F) substitution at position 18 in P.1 and R246I variants, an arginine (R) to isoleucine (I) substituted at position 246 in B.1.351.

B.1.427/B.1.429 and B.1.526 alsorecognized to have amino acid substitutions in the NTD (Ashley Hagen, 2021).

\subsection{RBD site variants}

The receptor binding domain (RBD) of $\mathrm{S}$ protein is comprised of amino acids 319-541 and it directly binds to ACE2 receptors. Therefore, mutations in this portion affects the antigenicity. The variants B.1.1.7, B.1.351 and P.1 have replacement of asparagine (N) with tyrosine (Y) at position 501 of the RBD, which results in reduced antibody production and binding to RBD (Vipin Vashistha, 2021).

Variants B.1.351 and P.1 have RBD mutations in common, K417N or $\mathrm{K} 417 \mathrm{~T}$, a lysine $(\mathrm{K})$ to asparagine $(\mathrm{N})$ or threonine $(\mathrm{T})$ substitution at position 417, and $\mathrm{E} 484 \mathrm{~K}$, a glutamate (E) to lysine (K) substitution at position 484, that increases the affinity of RBD for ACE2, resistance to antibody neutralization, and antibody mediated therapy. The California strain B.1.427 and B.1.429, both contain the same $3 \mathrm{~S}$ gene mutations. One of these, L452R, is a substitution that replaces leucine (L) with arginine (R) at position 452 and increased the affinity of RBD and cause severe infection (Meredith Wadman, 2021).

\subsection{Furin cleavage site variants}

Mutation in furin cleavage site of $S$ protein affects activation of virus to attach with the host cell. B.1.1.7 variant has a proline $(\mathrm{P})$ to histidine $(\mathrm{H})$ substitution at position 681 near the furin cleavage site.

B.1.351 and B.1.526 have an alanine (A) to valine (V) substitution at position $701(\mathrm{~A} 701 \mathrm{~V})$ that is still of which are of unknown function. Rapid rise in mutation at furin cleavage site resulted in emergence of 6 distinct variants having substitutional mutation at 677 position of furin cleavage site of $\mathrm{s}$ protein. Histine at $677^{\text {th }}$ position substituted with glutamine $(\mathrm{Q} 677 \mathrm{H})$ in B.1.2, B.1.234, B.1.1.220 and B.1.1.222 and other two variant showed presence of proline substituted glutamine at 677 position (Q677P). Increasing spread rate of these variants and infectivity proven that these mutations cause high potential functional relevance in cell entry and deliberate an advantage in spread or transmission (Hodcroft et al., 2021).

\subsection{C-terminus variants}

$\mathrm{S}_{2}$ helps in binding of spike protein with host cell membrane also undergoes multiple mutation effects in efficient binding with host or of unknown function. The variants B.1.1.7 and P.1 have multiple mutations in the $\mathrm{C}$-terminal domain of unknown significance.

\section{Mechanism of pathogenesis by SARS-CoV-2}

Biopsy of SARS-Cov-2 infected patients showed diffused alveolar sac and wall with the formation of hyaline membranes, mononuclear cells, and infiltration of macrophages in the filtrating air spaces. Presence of large number of viral particles were observed in the bronchial and type 2 alveolar epithelial cells under electron microscopy. In addition, spleen atrophy, lymph node necrosis, focal haemorrhage in the kidney, enlarged liver with inflammatory cell infiltration, oedema, and scattered degeneration of the neurons in the brain recorded in severely ill patients by autopsy suggesting multiple organ dysfunction (China National Health Commision, 2020 and Yao et al., 2020). However, there are no reports about broad dissemination of the viral particles by autopsy. Gastrointestinal tract and kidney cells expressing ACE-2 receptors also infected by SARS-CoV-2.

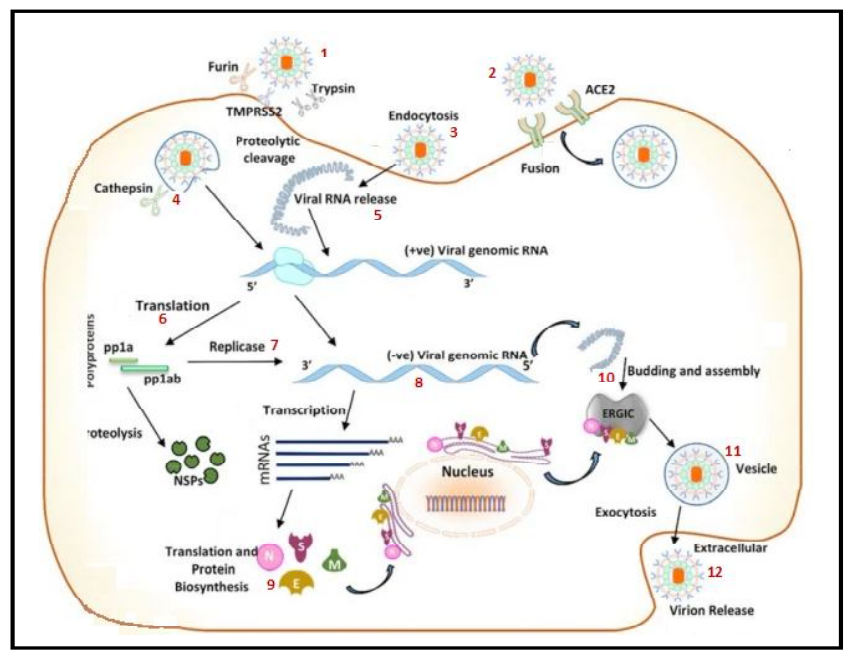

Figure 5: Life cycle of SARS-CoV-2 in human cell. *Source: Yesudhas et al., 2021 (CC).

The S protein present in the membrane of SARS-CoV-2 recognizes the host ACE- 2 receptor and binds to the receptor by activation of the spike protein by cleavage between S1 and S2 domain. TMPRSS2 is a serine protease present frequently in alveolar epithelial type II cells, it primes the spike-domain (S) of SARS-CoV-2 by cleaving as the S1/S2 sites. The spike protein is cleaved at S20 by TMPRSS2, results in the fusion of membranes with virus. After fusion with the host cell entry of viral RNA into the host cell by the clathrindependent, and/or clathrin-independent endocytosis (Wang et al., 2008) (Figure 5). By using the RNA dependent RNA polymerase enzyme, viral genome undergoes replication and transcribed to two structural proteins and polyproteins in the cytoplasm of the host cell. Simultaneously, host cell activates coordinated immune response through innate and adaptive immune response. In endosome, membrane specific pattern recognition receptors (PRR), such as tolllike receptor (TLR3, TLR8, TLR7, and TLR9) or the cytosolic RNA sensor, RIG-I/MDA5 or the secretory type PRR like mannose-binding lectin (MBL) and C-reactive protein (CRP) recognize viral RNA by pathogen-associated molecular patterns (PAMPs) (Perlman and Netland, 2009). Interferon (IFN-1) type I activate a potent innate immune response and adaptive immune response. A complex signaling cascade initiated by recruiting adaptor proteins such as mitochondrial antiviral-signaling protein (MAVS), IFN- $\beta$ (TRIF), and stimulator of interferon genes protein (STING) and activate downstream cascades 
molecules, like adaptor molecule MyD88. Stimulatory molecules further activates transcription factors like nuclear factor- $\mathrm{kB}$ (NF$\kappa \mathrm{B})$ and interferon regulatory factor 3 (IRF3) and helps in nuclear translocation. In the nuclei, these transcription factors induce the production of type I interferons (IFN- $\alpha / \beta$ ) and a plethora of proinflammatory cytokines especially IL-6 (Li et al., 2020). Type I IFN suppress viral replication and promote phagocytosis of antigens by macrophage, as well as NK cells mediated restriction of infected cells (Zhou et al., 2020).

Generally, Th1 mediated immune response plays a predominant role in T cell responses that depend upon the presence of APC (antigen presenting cells) mediated cytokine microenvironment. $\mathrm{CD} 8^{+}$cytotoxic $\mathrm{T}$ cells (CTLs) secrete granzymes, perforin, and IFN- $\gamma$ lyse the virus infected host cell and eradicate it. $\mathrm{CD} 4^{+}$Helper $\mathrm{T}$ cells induce the $\mathrm{T}$ cytotoxic cells and on the other hand, B-cell mediated humoral immune response. Through, the clonal propagation method induce the production of memory B cells and plasma cell against the each viral antigen to produce neutralizing antibody and prevent from further infection (Figure 5). Similar to SARS and MERS infection an elevated level of chemokines and plasma cytokines such as interleukins (IL-1, IL-2, IL-4, IL-7, IL-10, IL12, IL-13, and IL-17), IP-10, macrophage colony-stimulating factor (MCSF), MCP-1, GCSF, hepatocyte growth factor (HGF), IFN- $\beta$, MIP- $1 \alpha$, and TNF- $\alpha$, etc., are expressed from the virus infected cells referred as lymphopenia or cytokine storm (Moore and June, 2020) (Figure 6).
Cytokine storm is due to the deregulated and excessive immune responses that cause damage to the host body. The cytokine storm cause the severe cytolysis of organs (air sac/lung/kidney/spleen/ intestinal tract) and further viral infection such as acute respiratory distress syndrome (ARDS), pneumonitis, respiratory failure, sepsis shock, organ failure, and potentially death. Severity of COVID-19 in patients cause decrease in the number of circulating B cells, CD8 + cells, CD4 + cells, natural killers (NK) cells, and a decrease in eosinophils, monocytes, and basophils (Zhou et al., 2020). Apoptosis of endothelial cells and epithelial cells damages the pulmonary microvascular and alveolar epithelial cell barriers and causes vascular leakage and alveolar edema, eventually leading to hypoxia (oxygen deprived condition in the tissues). In severe case of ARDS innate immunity cause induction of hypoxia inducible factor- $1 \alpha(\mathrm{HIF}-1 \alpha)$ that cause up-regulation of vascular endothelial growth factor (VEGF). These factor induce the improper immune response by nonspecific inflammatory cell infiltration with increased vascular permeability leads to autophagy recruitment (Jahani et al., 2020). Autophagic recruitment cause blood (hypoxemia) and tissue (hypoxia) oxygenation plays major role in inflammation, capillary damage, organ failure and death due to collapse of lungs and cardiac arrest (Ostergaard, 2021). The cytokine storm is also a cause of death in ICU patients by increase the level of liver enzymes in gastrointestinal tract and creatinine levels in kidney that lead to extrapulmonary multiple-organ failure (Ye et al., 2020).

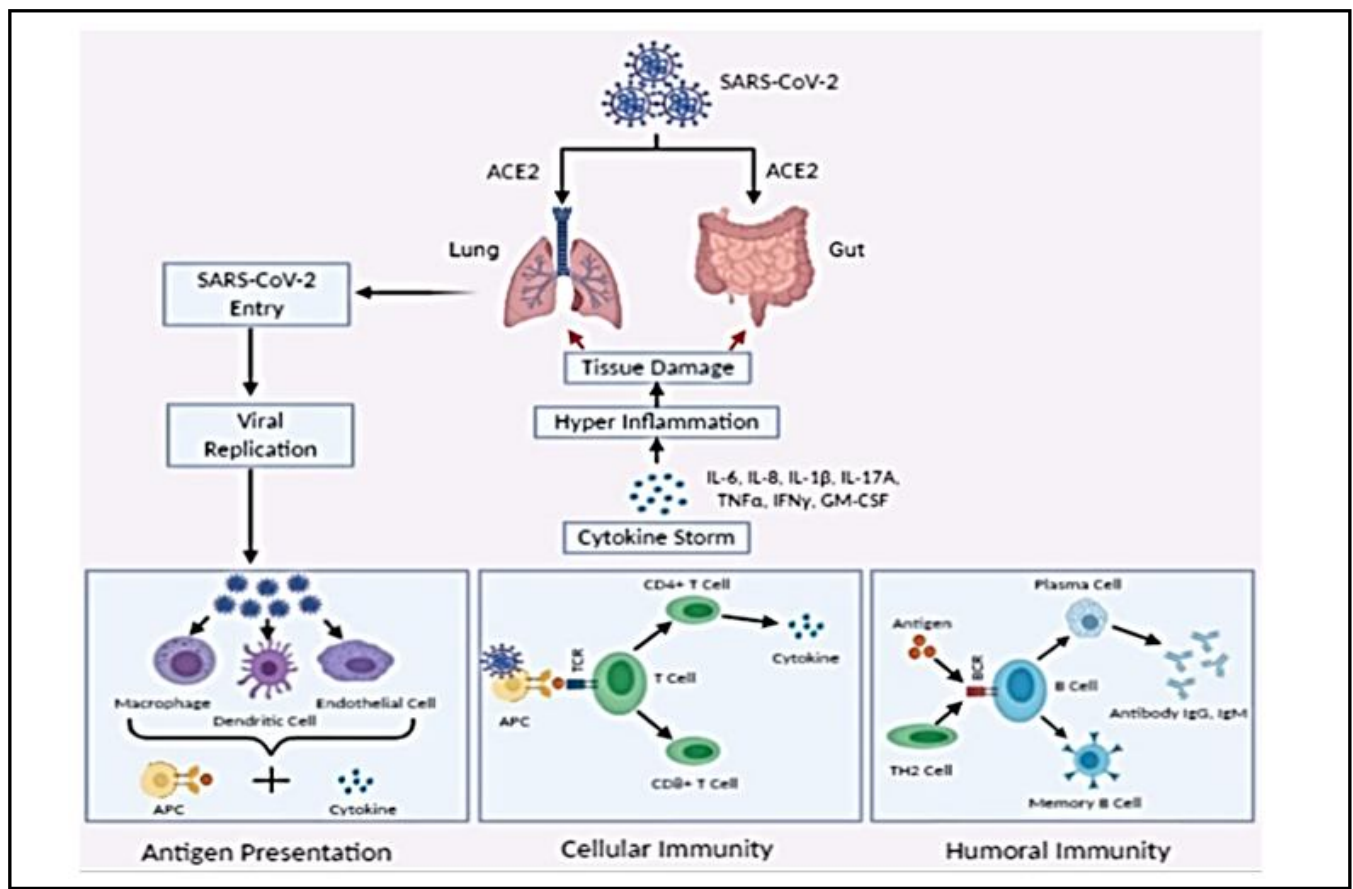

Figure 6: Immune response to SARS-CoV-2 infection in human body (Chatterjee et al., 2020).

In vitro cell experiments report that delayed release of cytokines and chemokines occurs in respiratory epithelial cells, dendritic cells (DCs), and macrophages at the early stage of SARS-CoV-2 infection completely arrest the host antiviral response in the host cells and induce inflammation. Later, the cells secrete low levels of the antiviral factors such as interferons (IFNs) and high levels of proinflammatory cytokines (interleukin (IL)-1 $\beta$, IL-6, and tumor necrosis factor (TNF)) and chemokines (C-C motif chemokine ligand (CCL-2, CCL-3, and CCL-5).

Delayed release of IFNs in the early stages of SARS-CoV and MERS$\mathrm{CoV}$ infection hinders the body's antiviral response (Channappanavar et al., 2019). Accelerated cytokine storm was also recognized and recorded in animal models such as mice, primates. In endothelial 
cell line model the production of IFN- $\alpha \beta$ and IFN- $\gamma$ induced inflammatory cell infiltration through mechanisms involving FasFas ligand (FasL) or trail-death receptor 5 (DR5) and cause the apoptosis of airway and alveolar epithelial cells (Rodrigue et al., 2014).

\section{Treatment}

Treatment for the COVID-19 infection developed by following two strategies: aimed to restrict or block the activity of the specific viral component or modulating host immune response. Again host

Table 2: Drugs used for treatment of SARS-CoV-2 infection

\begin{tabular}{|c|c|c|c|}
\hline Drug of choice & Mechanism of action & Outcome & References \\
\hline $\mathrm{IFN}-\lambda$ & $\begin{array}{l}\text { Activates epithelial cells and reduces the } \\
\text { mononuclear macrophage-mediated } \\
\text { proinflammatory activity of IFN- } \alpha \beta \text { inhibits } \\
\text { the recruitment of neutrophils to the sites } \\
\text { of inflammation activates the antiviral genes } \\
\text { in epithelial cells }\end{array}$ & $\begin{array}{l}\text { Early administration reducing viral } \\
\text { load }\end{array}$ & Davidson et al., 2016 \\
\hline $\begin{array}{l}\text { Corticosteroid } \\
\text { (Dexamethasone) }\end{array}$ & Suppress inflammation & $\begin{array}{l}\text { Treatment during initial period of } \\
\text { infection reduced the mortality rate. } \\
\text { But later cases caused increased } \\
\text { severity of infection large doses } \\
\text { delay the clearance of virus due to } \\
\text { immunosuppression }\end{array}$ & $\begin{array}{l}\text { Auyeung et al., } 2005 \text {; } \\
\text { Yam et al., } 2007\end{array}$ \\
\hline $\begin{array}{l}\text { Passive } \\
\text { immunization } \\
\text { with IgG } \\
\text { (casuruvumab/ } \\
\text { imdevimab) }\end{array}$ & immune substitution and immunomodulation & $\begin{array}{l}\text { Effective on original strain neutrali- } \\
\text { zation but not on variants }\end{array}$ & $\begin{array}{l}\text { Shakoory et al., 2016; } \\
\text { Fischer et al., } 2020\end{array}$ \\
\hline $\begin{array}{l}\text { Blockers of } \\
\text { VEGP }(e . g ., \\
\text { bevacizumab) }\end{array}$ & $\begin{array}{l}\text { Suppress the expression of VEGF and reduce } \\
\text { vascular permeability }\end{array}$ & Under clinical trials & Leah Shaffer, 2020 \\
\hline $\begin{array}{l}\text { Blockers of IL-1 } \\
\text { (e.g., anakinra) }\end{array}$ & Reduce the cytokine storm & $\begin{array}{l}\text { Improved survival rate of patients } \\
\text { with severe symptoms }\end{array}$ & Biggioggero et al., 2018 \\
\hline $\begin{array}{l}\text { Blockers of IL-6 } \\
(e . g ., \text { tocilizumab) }\end{array}$ & $\begin{array}{l}\text { Reduce the cytokine storm in severely } \\
\text { infected persons }\end{array}$ & $\begin{array}{l}\text { Improvise the severely inflamed } \\
\text { organs }\end{array}$ & Tanaka et al., 2016 \\
\hline Blockers of TNF & Blocks the receptors to bind with TNF & $\begin{array}{l}\text { Recommended during later stages of } \\
\text { infection. Prevent from lung damage. } \\
\text { Still need to explore }\end{array}$ & McDermott et al., 2016 \\
\hline $\begin{array}{l}\text { Inhibitor of } \\
\text { IFN- } \alpha \beta\end{array}$ & Prevent frominflammation & $\begin{array}{l}\text { Administrated only later stages of the } \\
\text { infection to reduce excessive } \\
\text { inflammatory responses }\end{array}$ & Davidson et al., 2015 \\
\hline Chloroquine & Inhibits the production of TNF and IL-6 & suppress the cytokine storm & Gao et al., 2020 \\
\hline $\begin{array}{l}\text { Hydroxychlo- } \\
\text { roquine }\end{array}$ & $\begin{array}{l}\text { Reduces the viral load during early stage of } \\
\text { infection }\end{array}$ & $\begin{array}{l}\text { Effect is enhanced by Azithromycin } \\
\text { administration }\end{array}$ & Gautret, et al., 2020 \\
\hline Ulinastatin & Naturalanti-inflammatory & $\begin{array}{l}\text { Protects the vascular endothelium } \\
\text { Reduce cytokine storm }\end{array}$ & Wang et al., 2019 \\
\hline $\begin{array}{l}\text { Inhibitors of } \\
\text { oxidised } \\
\text { phospholipids } \\
\text { (OxPL) }\end{array}$ & $\begin{array}{l}\text { Reduces the production of inflammatory } \\
\text { chemokines and cytokines }\end{array}$ & Reduce the rate of acute lung injury & Imai et al., 2008 \\
\hline $\begin{array}{l}\text { Antagonist to } \\
\text { sphingosine - } 1 \\
\text { phosphate } \\
\text { receptor }\end{array}$ & Prevent the synthesis of cytokines & $\begin{array}{l}\text { Reduces proinflammatory responses } \\
\text { in lungs }\end{array}$ & $\begin{array}{l}\text { Walsh et al., } 2011 \text {; } \\
\text { Teijaro et al., } 2011\end{array}$ \\
\hline
\end{tabular}

immune response modulated in two different ways for treatment: boosting immune response during initial stage of the infection and suppress the immune response during later/ high inflammatory stage of the infection. Many of the drugs are primarily targeted towards inactivation of virus specific components such as spike protein, $\mathrm{nsp}, \mathrm{RdRp}$, nucleocapsid phosphoprotein, RBP, inhibitors to 3chymotrypsin like protease (3CLpro), etc. Different drug components are already in use against SARS-CoV/ newly developed 2. The following table brief on drug candidates and their function (Table 2). drugs/ drugs under development are targeted towards the SARS-CoV- 


\begin{tabular}{|l|l|l|l|}
\hline $\begin{array}{l}\text { Mesenchymal } \\
\text { stem cell therapy }\end{array}$ & $\begin{array}{l}\text { Inhibit abnormal activation of Th1 cells and } \\
\text { innate immune cells }\end{array}$ & Alleviate ARDS & Uccelli et al., 2015 \\
\hline Blood dialysis & $\begin{array}{l}\text { Block cytokine storm and reduce the risk of } \\
\text { inflammation }\end{array}$ & Used to treat severely ill patients & Xu. K., et al., 2020 \\
\hline $\begin{array}{l}\text { Inhibitors of } \\
\text { macrophage } \\
\text { recruitment } \\
\text { (siRNA) }\end{array}$ & Completely reduces the inflammation & $\begin{array}{l}\text { Not clinically proven in COVID-19 } \\
\text { patients/ animal models }\end{array}$ & Leuschner et al., 2015 \\
\hline $\begin{array}{l}\text { Ivermectin } \\
\text { Remdesivir }\end{array}$ & $\begin{array}{l}\text { Binding and destabilizing cell transport } \\
\text { proteins }\end{array}$ & Still studies are going on. & Leah Shaffer, 2020 \\
\hline Lopinavir & $\begin{array}{l}\text { Inhibitor of viral protease -3-chymotrypsin } \\
\text {-like protease }\end{array}$ & Used along with ritonavir & Wang et al., 2020 \\
\hline Famotidine & May bind to papain-like protease & Prevent the entry of virus into cell & Freedberg et al., 2020 \\
\hline $\begin{array}{l}\text { Nafamostat } \\
\text { Serine protease inhibitors (TMPRSS2) }\end{array}$ & Inhibit viral cell entry & $\begin{array}{l}\text { Markus Hoffmann } \\
\text { et al., 2010 }\end{array}$ \\
\hline $\begin{array}{l}\text { Blood thinners/ } \\
\text { anticoagulants }\end{array}$ & $\begin{array}{l}\text { Heparin or warfarin. Prevent coagulation } \\
\text { of blood by SARS-CoV-2 }\end{array}$ & $\begin{array}{l}\text { Reduced the risk of blood coagulation. } \\
\text { Still research need to be done }\end{array}$ & $\begin{array}{l}\text { COVID-19 treatment } \\
\text { guidelines panel }\end{array}$ \\
\hline
\end{tabular}

\section{Probiotics in control of SARS-CoV-2}

Though, several drugs and natural components used for the treatment of COVID-19, the major role of human natural flora, friendly bacteria - probiotics their role in COVID -19 infection need to be elucidated. A potential therapy to block the multiplication of live organisms by other living organisms can be used to ensure continuous monitoring and regulation in the entry of pathogens into the body. The gastrointestinal tract of the human body includes bacteria, viruses, and fungi (Shi et al., 2017). The number of organisms varies from $10^{4}$ to $10^{5} \mathrm{CFU} /$ millimeter of the small intestine and $10^{11} \mathrm{CFU} /$ gram of lumen content of the colon (Thomas et al., 2017). Major gut probiotic microbiome includes Lactobacillus acidophilus, $L$. casei, L. paracasei, L. rhamnosus, L. delbrueckii subsp. bulgaricus, L. brevis, L. johnsonii, L. plantarum, L. fermentum, Saccharomyces boulardii, Bifidobacterium bifidum, Lactococcus lactis, etc. The probiotic microbial population in the gut comprises $90 \%$ of Firmicutes and Bacteroidetes followed by other Proteobacteria and Actinobacteria (Rinninella et al., 2019).

Previous clinical studies reported that probiotics prevent bacterial and viral infections, including gastroenteritis, sepsis, and respiratory tract infections especially highly active in controlling $80 \%$ of respiratory tract infections caused by respiratory syncytial virus, rhinoviruses and influenza viruses (Baud et al., 2020).The major proposed mechanism used to control SARS-CoV-2 by the probiotics includes (Al Kassaa et al., 2014);

i. Interaction of probiotics directly inhibit virus lodging in the host system

ii. Production of various antiviral metabolites

iii. Immunomodulation of host

\subsection{Competitive inhibition}

Enriching the gut with probiotic population competitively inhibits the virus loading and multiplication in the gut. The virus propagates and establishes in the host gut when dysbiosis of probiotic population. Administration of probiotic organisms cause gut mediated-pulmonary immunity in virus-infected host system and reclaim health (Gohil et al., 2021). Antagonism of probiotics on the virus and its immunomodulatory function ameliorated by the mixed consumption of probiotics with prebiotics (Olaimat et al., 2020). Probiotics reported to competitively inhibit HIV adsorption to the host by the production of sulfated exopolysaccharides and by surfactin produced by Bacillus subtilis OKB105 inhibits adsorption by transmissible gastroenteritis virus. Well-known entry and attachment site of the SARS-CoV-2 manipulated by the presence of well flourished probiotic community and has attracted as a potential therapeutic target for a number of diseases. In COVID-19 infection, probiotics exert pressure on the expression of angiotensin converting enzyme 2 (ACE-2) in the small bowel and colon and prevent gut inflammation (Segal et al., 2020). Establishment of SARS-COV-2 in the gut region reported replacing the beneficial probiotic bacteria (Eubacterium ventriosum, Faecalibacterium prausnitzii, etc.) with opportunistic pathogens (Clostridium hathewayi, Actinomyces isrellii, Bacteroides nordii). Further complications associated with viral infections enhanced by these opportunistic pathogens. Other physical factors which complicate the health of COVID-19 patients include old age, heart diseases, obesity, hypertension and diabetes mellitus (uptake of associated medicines) leads todysbiosis of probiotics, which contribute to the severity of infection (Mak et al., 2020).

\subsection{Antiviral metabolites}

Probiotic organisms produce various metabolites that inhibit the establishment of viruses in the host. Biosurfactants are surfaceactive molecules that disrupt the lipid envelope of the virus. Similarly, fermentation end products such as organic acids (butyric acid/ lactic acid) produced by the probiotic organism prevent the actuality of the virus in the gut and down-regulate the intestinal permeability by the virus. Production of butyric acid energies the intestinal colonocyte which in turn constricts the integrity at tight junction where SARS-CoV-2 attachment to the gut epithelial cells and colonization becomes challenging (Baud et al., 2020). Metabolites from Lactobacillus plantarum such as plantaricin, lactic 
acid, acetic acid, and gamma-aminobutyric acid showed antiviral activity by binding with the virus and prevent it from associating with host system. Molecular docking studies reported that complete detention of binding of RBD and spike protein with ACE-2 by the probiotic metabolite plantaricin $\mathrm{BN}$, plantaricin JLA-9, and plantaricin D. The maximum binding energies obtained with plantaricin W recorded as $-14.64,11.1$ and 12.68 for polymerase, RBD and ACE2. Plantaricin W, D, and JLA-9 were able to block the residues (THR556, ALA558) surrounding the catalytic site (VAL557) of RdRp in SARS-CoV-2. So, the potential of plantaricin to control SARS-CoV-2 established with in silico model (Anwar et al., 2020).

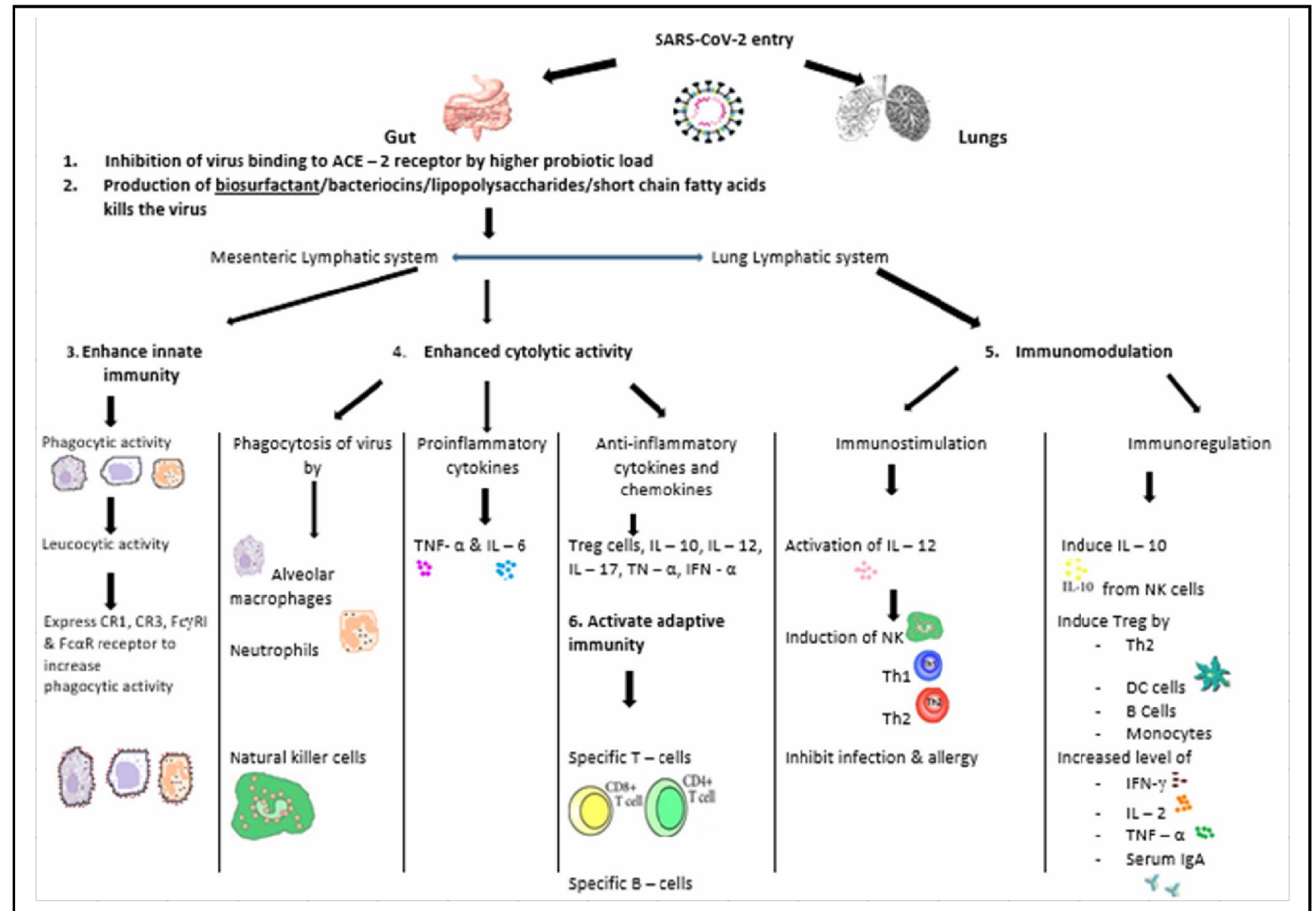

Figure 7: Immune mechanism to control SARS-CoV-2 by probiotics.

\subsection{Immunomodulation}

The probiotics are proven for their immunomodulatory effect upon viral infections in the human. Experimental data confirmed the increase in $\mathrm{T}$ helper cell-mediated immune response in influenza virus-infected parenchymal cells by Lactobacillus sp., and Bifidobacterium sp. Induction of phagocytosis of virus infected cells and increased innate immunity by the production of IL-4, IL-10, and IL-6 recorded in bronchoalveolar lavage by the $L$. rhamnosus and B. lactis. Clinical trials on the effect of probiotics in the management of SARS, MERS and SARS-CoV-2 need to be explored (Sundararaman et al., 2020). The probiotic organisms modulate the gut and lung by entering into the lymphatic system. From the mesenchyme lymphatic system moves to the lung lymphatic system and modulates the immunity of the host. Actually, major sites of multiplication of SARS-CoV-2 in the host are the lung and gut. Immunomodulation in these regions certainly affects the pathogenicity of the virus. In the early stage of viral infection, inflammation and poor immune response result insevere pathological condition, in later stages excess of the immune response or cytokine storm leads to a sudden collapse in the host. Both immunological conditions are well maintained by the probiotic immunomodulatory function. First of all, probiotics enhance innate immunity by the cytolytic activity of macrophages, monocytes, neutrophils, natural killer cells, and allied cytokines to destroy the virus-infected cells. Secondly, by immunostimulatory task, activates the specific T-cells to induce cytotoxic activity and inflammatory mediators. Next by immunoregulation, triggers the specific neutralizing antibody production, meantime regulates the excess/uncontrolled expression of cytokines by treg mediators such as Th2, dendritic cells, and monocytes. Also regulate the inflammation, induction of IFN- $g$ enhance $B$ cell-mediated adaptive immunity and complement fixing antibodies (Figure 7). By the induction of treg mediators such as IL-25 migration of lymphoid cells from the gut to the lungs to dislodgement of pathogens recorded (Huang et al., 2018). Bifidobacteria recognized to have the potential to ameliorate the viral cytokine storm through regulated expression of pro and anti-inflammatory cytokines (Hüseyin et al., 2020). 
The theoretical studies and experimental data of other viral infections concluded that probiotic bacteria may catalyze immune homeostasis during coronavirus-infections (Singh and Rao, 2021). Thus, the probiotics functions as live neutraceutical and life-saving immunobiotic from infections caused by SARS-CoV-2 and its variants. Also recommended that in absence of efficient treatment strategy, probiotics also used parallel with other treatment method (Gohil et al., 2021). Still, clinical studies on the mechanism of action of probiotics in vivo condition needs to be established in COVID-19 patients.

\section{Future prospects}

SARS-CoV-2 is the variant of the SARS virus, drastically affecting human society and the economy. The virus is mutating at a faster rate and adapting to escape from drugs that are used for treatment. Similarly, already developed vaccines reported to have less efficacy in combating the viral variants. The $86 \%$ efficiency of Covishield vaccine towards the wild type strain reduced to less than $63 \%$ on B.1.1.7 variant, $5 \%$ reduction in the efficacy of Novavax vaccine reported on variants $(89 \%)$ versus non-variant strain $(84 \%)$, and Astra Zeneca vaccine efficacy reduced from $84 \%$ on non-variant to $74 \%$ on variant strains. A ten-fold efficacy reduction in Pfizer and Moderna vaccine, $40 \%$ reduction of efficacy of Novavox against South African variant reported. Moreover, in the city of Manaus, Brazil about $70 \%$ of the persons already infected by the wild type strain of SARS-CoV-2 and acquired natural immunity toward the virus. But, records shows that again vaccinated individuals infected by the variant of SARS-CoV-2. These study results envisaged the inefficacy of natural immunity and acquired immunity (through vaccines) to prevent infections caused by variants. As the number of vaccines and drugs are developing, parallel variants also emerging. So, a live immune booster that continuously enhances the host immunity and competitively inhibits the entry of the virus can assure the remedy to viral infection. Also, pathological viruses cannot be eradicated by a single mechanism such as by administration of drug or vaccine as the virus is showing phase shift. An immunomodulator along with drugs or vaccines can complement the activity and eradicate the virus and its variants. An exploratory in vivo studies required to address the full proof of concept on the immunomodulatory effect of probiotic to control SARS-CoV-2.

\section{Conflict of interest}

The authors declare that there are no conflicts of interest relevant to this article.

\section{References}

Al Kassaa, I.; Hober, D.; Hamze, M.; Chihib, N.E. and Drider, D. (2014). Antiviral potential of lactic acid bacteria and their bacteriocins. Probiot Antimicrob Proteins, 6:177-185.Doi: 10.1007/s12602-014-9162-6.

Ankur Das, Raja Ahmed; Suraiya Akhtar; Khaleda Begum and Sofia Banu (2021). An overview of basic molecular biology of SARS-CoV-2 and current COVID-19 prevention strategies, Gene Reports, 23:101-122, Doi: 10.1016/j.genrep.2021.101122.

Anwar, F.; Altayb, H.N.; Al-Abbasi, F.A.; Al-Malki, A.L.; Kamal, M.A. and Kumar V. (2020). Antiviral effects of probiotic metabolites on COVID-19 (published online ahead of print, 2020 Jun 9). J. Biomol. Struct. Dyn., pp:1-10. doi:10.1080/07391102.2020.1775123
Ashley Hagen, M.S. (2021). American Society for Microbiology. SARS-CoV2 Variants vs. vaccines. American Society for Microbiology. March 2021. https://asm.org/Articles/2021/February/SARS-CoV-2Variants-vs-Vaccines.

Auyeung, T.W.; Lee, J.S.W.; Lai, W.K.; Choi, C.H.; Lee, H.K. and Lee J.S. (2005). The use of corticosteroid as treatment in SARS was associated with adverse outcomes: A retrospective cohort study. J Infect., 51(2):98102. PubMed PMID: 16038758.

Banerjee, A.K.; Blanco, M.R.; Bruce, E.A.; Honson, D.D.; Chen, L.M. and Chow, A. (2020). SARS-CoV-2 disrupts splicing, translation, and protein trafficking to suppress host defenses. Cell, https://doi.org/10.1016/ j. cell.2020.10.004.

Biggioggero, M.; Crotti, C.; Becciolini, A. and Favalli, E.G. (2018). Tocilizumab in the treatment of rheumatoid arthritis: An evidence-based review and patient selection. Drug Design, Devel Therapy, 13:5770. PubMed PMID: 30587928.

BioRxiv (2020).1 0.17.343749; doi: https://doi.org/10.1101/2020. 10.17.343749. This article is a preprint and has not been certified by peer review.

By Kevin, R. Mccarthy; Linda, J. Rennick; Sham Nambulli; Lindsey R. RobinsonMccarthy; William G. Bain; Ghady Haidar, W. and Paul Duprex. (2021). Recurrent deletions in the SARS-CoV-2 spike glycoprotein drive antibody escape. Science, 12:1139-1142.

By Yan Gao; Liming Yan; Yucen Huang; Fengjiang Liu. and Yao Zhao. (2020). Structure of the RNA-dependent RNA polymerase from COVID-19 virus. Science, 20:779-782.

Center for Disease Control (2020). Science Brief: Emerging SARS-CoV-2 Variants. News, January 28:2021.

Channappanavar, R.; Fehr,A. R.; Zheng, J.; Wohlford-Lenane, C.; Abrahante, J.E.; Mack, M.; Sompallae, R. and McCray, P. B. (2019). IFN-I response timing relative to virus replication determines MERS coronavirus infection outcomes. The Journal of Clinical Investigation, 129(9):3625-3639. https://doi.org/10.1172/JCI126363.

Chatterjee, S. K; Saha, S. and Munoz, M. N. M. (2020). Molecular pathogenesis, immunopathogenesis and novel therapeutic strategy against COVID19. Front. Mol. Biosci., 7:196. doi: 10.3389/fmolb. 2020. 00196.

Chen, R.C.; Tang, X.P.; Tan, S.Y.; Liang, B.I.; Wan, Z.Y. and Fang, J. Q. (2016). Treatment of severe acute respiratory syndrome with glucosteroids: The Guangzhou Experience. Chest, 129(6):1441-1452. 2006/06/ $01 \%$.

China National Health Commision. (2020). Diagnosis and treatment of novel coronavirus pneumonia in China (trial version 7).https://www.who. int/docs/default-source/wpro-documents/countries/china/covid-19briefing-nhc/1-clinical-protocols-for-the-diagnosis-and-treatmentof-covid-19-v7.pdf?sfvrsn=c6cbfba4_2

Chowdhury, M.A; Hossain, N.; Kashem, M.A.; Shahid, M.A. and Alam, A. (2020). Immune response in COVID-19: A review. J. Infect. Public Health, 13(11):1619-1629. doi:10.1016/j.jiph.2020.07.0.

COVID-19 Treatment Guidelines Panel (2021). Coronavirus disease 2019 (COVID-19). Treatment guidelines. National Institutes of Health. available at https://www.covid19treatmentguidelines.nih.gov/. accessed (23 ${ }^{\text {rd }}$ April 2021).

Davidson, S.; Maini M.K. and Wack A. (2015). Disease-promoting effects of type I interferons in viral, bacterial, and coinfections. J. Interf Cytokine Res. Offic J. Int. Soc. Interf. Cytokine Res., 35(4):252264. PubMed PMID: 25714109

Davidson, S.; McCabe, T.M.; Crotta, S.; Gad, H.H.; Hessel E.M. and Beinke S. (2016). IFN $\gamma$ is a potent anti-influenza therapeutic without the inflammatory side effects of IFN $\alpha$ treatment. EMBO Molecul. Med. 8(9):1099-1112. Pub. Med., PMID:27520969. 
Davies, N.G; Abbott, S. and Barnard, R.C. (2021). Estimated transmissibility and impact of SARS-CoV-2 lineage B.1.1.7 in England. MedRXiv. doi: https://doi.org/10.1101/2020.12.24.20248822.

Deng, X.; Garcia-Knight, M.A. and Khalid, M.M. (2021). Transmission, infectivity, and antibody neutralization of an emerging SARS-CoV-2 variant in California carrying a L452R spike protein mutation. MedRxiv 2021. doi: https://doi.org/10.1101/2021.03.07.21252647

Emary, K.R.W.; Golubchik, T. and Aley, P.K. (2021). Efficacy of ChAdOx1 nCoV-19 (AZD1222) vaccine against SARS-CoV-2 VOC 202012/ 01 (B.1.1.7). The Lancet, doi: http://dx.doi.org/10.2139/ ssrn. 3779160

Emma, B. Hodcroft; Daryl B. Domman; Daniel J. Snyder; Kasopefoluwa Y. Oguntuyo; Maarten Van Diest and Kenneth H. Densmore, (2021). Emergence in late 2020 of multiple lineages of SARS-CoV-2 Spike protein variants affecting amino acid position 677. Medrix. BMJ.medRxiv 2021. 02.12.21251658;doi: https://doi.org/10.1101/ 2021.02.12. 21251658.

Evgeny, V. Mavrodiev; Melinda L. Tursky; Nicholas E. Mavrodiev; Malte C. Ebach; David M. Williams; and Riboviria; Nidovirales. (2020). On classification and taxonomy of coronaviruses coronaviridae with the special focus on severe acute respiratory syndrome-related coronavirus 2 (SARS-Cov-2). bioRxiv. doi: https://doi.org/10.1101/ 2020.10.17.343749.

Fact Sheet For Health Care Providers. (2020). Emergency use authorization (Eua) of bamlanivimab and etesevimab 02092021 (fda.gov) external icon.

Fischer, J.C.; Zänker, K.; van Griensven, M. (2020).The role of passive immunization in the age of SARS-CoV-2: An update. Eur. J. Med. Res., 25:16 (2020). https://doi.org/10.1186/s40001-020-00414-5

Freedberg, D. E.; Conigliaro, J.; Wang, T. C.; Tracey, K. J.; Callahan, M. V. and Abrams, J. A. (2020). Famotidine research group. Famotidine use is associated with improved clinical outcomes in hospitalized COVID19 patients: A propensity score matched retrospective cohort study. Gastroenterology,159(3):1129-1131.e3. doi: 10.1053/j.gastro .2020.05.053. Epub 2020 May 22. PMID: 32446698; PMCID: PMC7242191.

Gao, J.; Tian, Z. and Yang, X.(2020). Breakthrough: Chloroquine phosphate has shown apparent efficacy in treatment of COVID-19 associated pneumonia in clinical studies. Biosci. Trends, 4:72-73

Gautret, P.; Lagier, J.C.; Parola, P.; Hoang, V.T.; Meddeb, L.; Mailhe, M.; Doudier, B.; Courjon,J.; Giordanengo, V. and Vieira, V.E. (2020). Hydroxychloroquine and azithromycin as atreatment of COVID-19: results of an openlabel non-randomized clinical trial. Int. J.Antimicrob. Agents. Published online March 20:20-20.

Gohil, K.; Samson, R.; Dastager, S. and Dharne, M. (2021). Probiotics in the prophylaxis of COVID-19: Something is better than nothing. 3 Biotech. 11:1-10. 10.1007/s13205-020-02554-1Gralinski LE, Menachery VD. Return of the Coronavirus: 2019-nCoV. Viruses. 2020 Jan 24;12(2):135. doi: 10.3390/v12020135.

Horby, P.; Huntley, C. and Davies, N. (2021). NERVTAG note on B.1.1.7 severity. New and emerging threats advisory group, Jan. 21. Retrieved from NERVTAG note on variant severity external icon.

Huang, Y. J.; Erb-Downward, J. R.; Dickson, R.; Curtis, J. L.; Huffnagle, G. B. and Han, M. K. (2017). Understanding the role of the microbiome in COPD principles, challenges and future directions. Transl Res., 179:7183. doi:10.1016/j.trsl.2016.06.007.

Hüseyin, S. Bozkurt; Eamonn, M. M. and Quigley. (2020). The probiotic bifidobacterium in the management of coronavirus: A theoretical basis. International Journal of Immunopathology and Pharmacology, doi.org/10.1177/2058738420961304.

Imai, Y.; Kuba, K.; Neely, G.G.; Yaghubian-Malhami R.; Perkmann, T. and Van Loo G. (2008). Identification of oxidative stress and toll-like receptor 4 signaling as a key pathway of acute lung injury. Cell, 133(2):235249. PubMed PMID: 18423196.
Jahani, M.; Dokaneheifard, S. and Mansouri, K. (2020). Hypoxia: A key feature of COVID-19 launching activation of HIF-1 and cytokine storm. J. Inflamm., 17:33 https://doi.org/10.1186/s12950-020-00263-3.

Jin, Z.; Du, X.; Xu, Y.; Deng, Y.; Liu, M. and Zhao Y. (2020). Structure of M(pro) from SARS-CoV-2 and discovery of its inhibitors. Nature, 582:289293. doi: 10.1038/s41586-020-2223-y

Leah Shaffer, (2020). 15 drugs being tested to treat COVID-19 and how they would work. Nature Medicine, 15th May 2020. Doi: https://doi.org/ 10.1038/d41591-020-00019-9.

Leuschner, F.; Courties, G.; Dutta, P.; Mortensen, L.J.; Gorbatov, R. and Sena, B. (2020). Silencing of CCR2 in myocarditis. Eur. Heart. J., 36(23):14781488. PubMed PMID:24950695. Epub 2014/06/20.

Li, G.; Fan, Y.; Lai, Y.; Han, T.; Li, Z. and Zhou, P. (2020). Coronavirus infections and immune responses. J. Med.Virol., 92:424-432. doi: 10.1002/ jmv. 25685

Liu, Y; Liu, J. and Xia, H. (2021). Neutralizing Activity of BNT162b2-Elicited Serum. NEJM. DOI: 10.1056/NEJMc2102017.

Mak, J.W.Y.; Chan F.K.L. and Ng, S.C. (2020). Probiotics and COVID-19: One size does not fit all. Lancet Gastroenterol. Hepatol., 5:644-45.

Markus Hoffmann; Hannah Kleine-Weber; Simon Schroeder; Nadine Krüger; Tanja Herrler; Sandra Erichsen; Tobias S. Schiergens; Georg Herrler; NaiHuei Wu; Andreas Nitsche; Marcel A. Müller; Christian Drosten and Stefan Pöhlmann (2020). SARS-CoV-2 cell entry depends on ACE2 and TMPRSS2 and is blocked by a clinically proven protease inhibitor. Cell, 181(2):271-280.e8. https://doi.org/10.1016/j.cell.2020.02.052.

McDermott, J.E.; Mitchell, H.D.; Gralinski, L.E.; Eisfeld, A.J.; Josset, L. and Bankhead A. (2016). The effect of inhibition of PP1 and TNF $\alpha$ signaling on pathogenesis of SARS coronavirus. BMC Syst. Biol., 10(1):93.

Meredith Wasman (2021). California coronavirus strain may be more infectious - and lethal. Health, coronavirus. Science., 2021. doi: $10.1126 /$ science.abh2101

Moore, J.B. and June, C.H. (2020). Cytokine release syndrome in severe COVID-19. Science, 368:473-474. doi:10.1126/science.abb8925.

Yesudhas, D.; Srivastava, A. and Gromiha, M.M. (2021). COVID-19 outbreak: History, mechanism, transmission, structural studies and therapeutics. Infection, 49:199-213.https://doi.org/10.1007/s15010-02001516-2

Naqvi, A.A.T.; Fatima, K.; Mohammad, T.; Fatima, U.; Singh, I. K. and Singh, A. (2020). Insights into SARS-CoV-2 genome, structure, evolution, pathogenesis and therapies: Structural genomics approach. Biochim. Biophys. Acta. Mol. Basis Dis., 18:66165878. doi: 10.1016/ j.bbadis.2020.165878.

Olaimat, A.N.; Aolymat, I. and Al-Holy, M. (2020). The potential application of probiotics and prebiotics for the prevention and treatment of COVID-19. npj Sci. Food, 4:17. https://doi.org/10.1038/s41538-02000078-9.

Østergaard, L. (2021). SARS CoV-2 related microvascular damage and symptoms during and after COVID-19: Consequences of capillary transit-time changes, tissue hypoxia and inflammation. Physiological Reports, 9(3):e14726. https://doi.org/10.14814/ phy 2.14726.

Perlman, S. and Netland, J. (2009). Coronaviruses post-SARS: Update on replication and pathogenesis. Nat. Rev. Microbiol., 7:439-450. doi: $10.1038 /$ nrmicro 2147.

Petersen, E.; Koopmans, M.; Go, U.; Hamer, D.H.; Petrosillo, N.; Castelli F.; Storgaard, M.; and Simonsen, L. (2020). The Lancet Infectious Diseases, 20(9):e238-e244.

Plante, J.A.; Liu, Y. and Liu, J. (2021). Spike mutation D614G alters SARS-CoV2 fitness. Nature, 592:116-121. https://doi.org/10.1038/s41586020-2895-3 
Rinninella, E.; Raoul, P.; Cintoni, M.; Franceschi, F; Donato Miggiano, G.A.; Gasbarrini, A. and Mele, M.C. (2019). What is the healthy gut microbiota composition? A changing ecosystem across Age, Environment, diet, and diseases. Microorganisms, 7:14. doi: 10.3390/microorganisms 7010014

Rodrigue-Gervais, I.G.; Labbé, K.; Dagenais, M.; Dupaul-Chicoine, J.; Champagne, C. and Morizot, A. (2014). Cellular inhibitor of apoptosis protein cIAP2 protects against pulmonary tissue necrosis during influenza virus infection to promote host survival. Cell Host Microbe, 15(1):2335. PubMed PMID: 24439895.

Segal, J. P.; Mak, J. W. Y.; Mullish, B. H.; Alexander, J. L.; Ng, S.C. and Marchesi, J. R. (2020). The gut microbiome: an under-recognised contributor to the COVID-19 pandemic? Therapeutic Advances in Gastroenterology. January 2020. doi:10.1177/1756284820974914.

Shakoory, B.; Carcillo, J.A.; Chatham, W.W.; Amdur, R.L.; Zhao, H. and Dinarello, C.A. (2016). Interleukin-1 receptor blockade is associated with reduced mortality in sepsis patients with features of macrophage activation syndrome: Reanalysis of a prior phase III trial. Critical Care Med., 44(2):275-281. PubMed PMID: 26584195.

Shi, N.; Li, N.; Duan, X. and Niu, H. (2017). Interaction between the gut microbiome and mucosal immune system. Mil. Med. Res., 4:14. doi: 10.1186/s40779-017-0122-9.

Singh, K. and Rao, A. (2021). Probiotics: A potential immunomodula-tor in COVID-19 infection management. Nutr. Res., 87:1-12. doi:10.1016/ j.nutres.2020.12.014

Sundararaman, A.; Ray, M.; Ravindra, P. V. and Halami, P.M. (2020). Role of probiotics to combat viral infections with emphasis on COVID19. Appl. Microbiol. Biotechnol., 104(19):8089-8104. doi:10.1007/ s00253-020-10832-4

Tai, W.; He, L.; Zhang, X.; Pu, J.; Voronin, D. and Jiang, S. (2020). Characterization of the receptor-binding domain (RBD) of 2019 novel coronavirus: implication for development of RBD protein as a viral attachment inhibitor and vaccine. Cell. Mol. Immunol., 20:1-8.

Tanaka, T.; Narazaki, M. and Kishimoto, T. (2016). Immuno therapeutic implications of IL-6 blockade for cytokine storm. Immunotherapy., 8(8):959-970. PubMed PMID: 27381687

Teijaro, J.R.; Walsh, K.B.; Cahalan, S.; Fremgen, D.M.; Roberts, E. and Scott, F. (2011). Endothelial cells are central orchestrators of cytokine amplification during influenza virus infection. Cell, 146(6):980991. PubMed PMID: 21925319.

Uccelli, A. and de Rosbo, N.K. (2015). The immunomodulatory function of mesenchymal stem cells: Mode of action and pathways. Ann. N.Y. Acad. Sci., 1351(1):114-126.

Vipin, Vashistha (2021). Are the new variants driving India's second COVID19 Wave?. March 2021. Health, the Science, https://science. the wire.in/the-sciences/are-the-new-variants-driving-indias-secondcovid-19-wave.

Walsh, K.B.; Teijaro, J.R.; Rosen, H. and Oldstone, M.B.A. (2011). Quelling the storm: Utilization of sphingosine-1-phosphate receptor signaling to ameliorate influenza virus-induced cytokine storm. Immunol. Res., 51(1): 15. 2011/09/08.
Wang, H.; Liu, B. and Tang, Y. (2019). Improvement of sepsis prognosis by ulinastatin: A systematic review and meta-analysis of randomized controlled trials (published correction appears in Front Pharmacol. Front. Pharmacol., 10:13-70. Published 2019 Nov 26. doi:10.3389/fphar.2019.01370

Wang, M.; Cao, R. and Zhang, L. (2020). Remdesivir and chloroquine effectively inhibit the recently emerged novel coronavirus (2019nCoV) in vitro. Cell. Res., 30:269-271.

Wang, Mei Yue; Thao Rong; Gao Li-Juan; Gao Xue-Fei; Wang De-Ping and Cao JiMin. (2020). SARS-CoV-2: Structure, biology, and structure-based therapeutics development. frontiers in cellular and infection Microbiology, 10:724. DOI:10.3389/fcimb.2020.587269.

Wang, M. Y.; Zhao, R.; Gao, L.J.; Gao, X. F.; Wang, D. P. and Cao J. M. (2020). SARSCoV-2: Structure, biology, and structure-based therapeutics Development. Front. Cell. Infect. Microbiol., 10:587269. doi: 10.3389/fcimb. 2020.587269

Wang, H.; Yang, P.; Liu, K.; Guo, F.; Zhang, Y. and Zhang, G. (2008). SARS coronavirus entry into host cells through a novel clathrin- and caveolae-independent endocytic pathway. Cell Res., 18:290-301. doi: $10.1038 / \mathrm{cr} .2008 .15$

Weisblum, Y.; Schmidt, F. and Zhang, F. (2020). Escape from neutralizing antibodies by SARS-CoV-2 spike protein variantsexternal icon. external icon. eLife 2020;9:e61312.

Wrapp, D.; Wang, N.; Corbett, K. S.; Goldsmith, J. A.; Hsieh, C. L. and Abiona, O. (2020). Cryo-EM structure of the 2019-nCoV spike in the prefusion conformation. Sci.(N.Y.N.Y.), 367:1260-1263.doi: 10.1126/ science.abb2507.

Xu, K.; Cai, H.; Shen, Y.; Ni, Q.; Chen, Y.; Hu, S.; Li, J.; Wang, H.; Yu, L.; Huang, H.; Qiu, Y.; Wei, G.; Fang Q.; Zhou, J.; Sheng, J.; Liang, T. and Li , L. (2020). Management of corona virus disease-19 (COVID-19): the Zhejiang experience. Zhejiang Da Xue Xue Bao Yi Xue Ban. 2020 Feb 21;49(1):147-157. Chinese. doi: 10.3785/j.issn.1008-9292.2020. 02.02. PMID: 32096367.

Yam, L.Y.C.; Lau, A.C.W.; Lai, F.Y.L.; Shung, E.; Chan, J. and Wong, V. (2020). Corticosteroid treatment of severe acute respiratory syndrome in Hong Kong. J. Infect., 54(1):28-39. PubMed PMID: 16542729. Epub 2006/03/15.

Yao, X. H.; Li, T. Y. and He, Z.C. (2020). A pathological report of three COVID19 cases by minimally invasive autopsies. Zhonghua Bing Li Xue Za Zhi., 49(in Chinese).: E009

Ye, Q.; Wang, B. and Mao, J.(2020). The pathogenesis and treatment of the 'Cytokine Storm' in COVID-19. J. Infect., 80(6):607-613. doi:10. 1016/j.jinf.2020.03.037.

Zhang, W.; Davis, B. D.; Chen, S. S.; Sincuir Martinez, J. M.; Plummer, J. T. and Vail, E. (2021). Emergence of a novel SARS-CoV-2 variant in Southern California. JAMA, 325(13):1324-1326. doi:10.1001/jama. 2021. 1612

Zhang, L.; Jackson, C.B. and Mou, H. (2020). SARS-CoV-2 spike-protein D614G mutation increases virion spike density and infectivity. Nat. Commun., 11:6013 https://doi.org/10.1038/s41467-020-19808-4.

Zhou, Z.; Ren, L.; Zhang, L.; Zhong, J.; Xiao, Y. and Jia, Z. (2020). Heightened innate immune responses in the respiratory tract of COVID-19 Patients. Cell Host Microbe, 27:883-890.e2. doi: 10.1016/ j.chom.2020.04.017. 